\title{
Sustainable Urban Development for Costal City Case Study: Bourg El-Bourols City
}

\author{
Amany Ragheb ${ }^{*}$, Haithem El Sharnouby ${ }^{2}$ \\ ${ }^{1}$ Department of Architectural, Faculty of Engineering, Delta University for Science \& Technology, Mansoura 11152, Egypt \\ ${ }^{2}$ High Institute of Engineering and Technology, Buhaira 22751, Egypt
}

Corresponding Author Email: raghebamany@yahoo.com

https://doi.org/10.18280/ijsdp.160605

Received: 29 July 2021

Accepted: 10 October 2021

\section{Keywords:}

sustainable urban development, costal city, urban space optimization, environment, GIS, Burj Al-Burullus

\begin{abstract}
Comprehensive urban development varies from place to place according to the different natural environment, unplanned urban development on coastal cities led to an urban disruption and random possession of lands, Burj Al-Burullus is a coastal city with high environmental sensitivity and has many environmental, social, and cultural systems that qualify it to be a development area with a distinct character. The challenges of urban development represent the biggest challenge to development in the region. Despite the presence of many development plans in the region, there is no clear methodology that considers the resources and the distinct potentials of these areas to make use of them in solving the problems that hinder development. The research presents an attempt to reach a mechanism through which sustainable urban development can be achieved in all economic, social, and demographic aspects. In addition, it contributes to formulating a vision and developing a strategy to achieve sustainable urban development, with the participation of economic institutions in a way that stimulates these institutions to invest. The research studies and evaluates the current reality of Burj Al-Burullus city using GIS in terms of the characteristics and activities of the city and explores its developmental reality. The research attempts to find appropriate urban solutions to overcome these urban challenges and develop plans to be used as a link between the challenges and development results and to be followed in the development of the region and similar areas.
\end{abstract}

\section{INTRODUCTION}

Egyptian cities have faced several challenges since the beginning of the new millennium such as rapid population growth, urban decay at the expense of available shelter, services, degradation of infrastructure and land, environmental deterioration, social structure, and the economy in general. All these factors led to unsustainable living [1].

The spread of urbanization in the new coastal areas far from the cities helped to spread the random growth of urbanization in a way that is difficult to control and manage on a regular basis [2]. Urbanization of coastal area has become a threat to coastal and natural resources [3]. Unplanned urban development which has been established on these coasts led to an urban disruption and random possession of land that necessitated the rapid intervention of the country [4].

The country has established management systems for coastal areas and developed methods to control the growth of coastal and urban activities in them. Therefore, the concept of comprehensive coastal development appeared along with the concept of sustainable development to preserve coastal and natural resources and protect the environment from unplanned coastal uses [5].

The general framework for the comprehensive urban development of the coasts involves the integration of the strategic plans of the various development sectors with the national urban strategy and urban development plans for residential communities, commercial and industrial ports [6], in addition to tourism activities and industrial and productive projects built on these coasts. Therefore, for a better preparation of comprehensive development plans for these coasts, it is necessary to take these activities into account and study the planning and strategic studies prepared for urban, sectorial, and economic development on coasts $[7,8]$, in addition to the constrains imposed by the environmental characteristics, security necessities and the current conditions.

Kafr El Sheikh Governorate is one of the governorates that have a distinguished geographical location in the Delta region in the north of the Arab Republic of Egypt [9], It contains major economic, social, and environmental factors that make investment in development projects a top priority for the national economy advancement plans. Based on determining the development sectors in Kafr El-Sheikh Governorate, the northwestern coast of the governorate has been placed in the priorities of the state's development plans due to its large economic, societal, and environmental factors [10], Several development axes were identified, where the development of Lake Burullus is taken as apriority to protect its ecological environment Figure 1 [11].

The area of Al-Burullus, located in the northern part of the Egyptian Delta, is a bustling commercial and administrative center. It is one of five protected lakes in Egypt that accommodate both a leisure summer resort and a poor stay throughout the year [12]. The lake, over time, has faced many changes with respect to the surrounding cities, which in turn have greatly affected the shore. Changes in land use and nature have altered the shoreline and will ultimately lead to many environmental and urban changes as well [13]. 

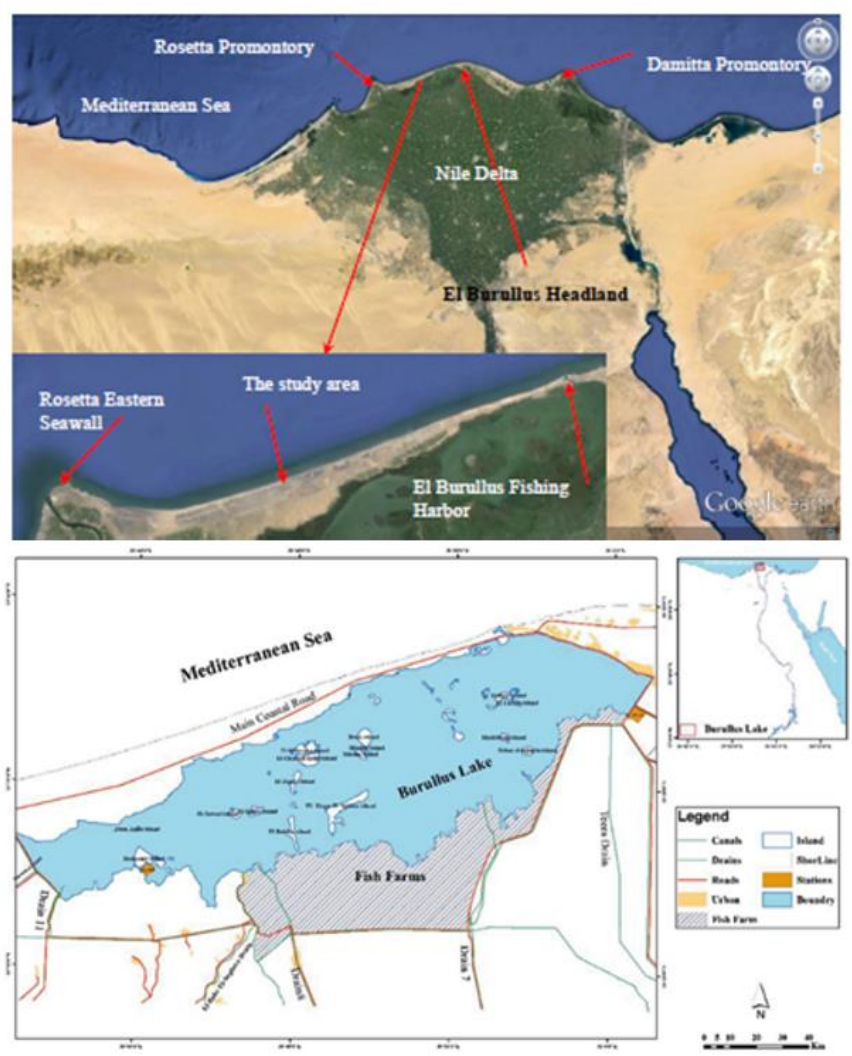

Figure 1. Map showing the districts surrounding Lake Burullus [12]

A lot of measures must be taken when considering future extensions of cities that have natural edges such as Lake Burullus and the vast agricultural lands [14]. The abovementioned challenges will face the existing societies, extend in relation to the surrounding areas, and thus contribute to changing the identity of the region.

This paper focuses on the importance of urban development and solutions for the cities surrounding Lake Burullus as well as coastal protection and implementation policies to improve the degradation of the coastline, considering the importance of rural regeneration and its impact on this area. It concludes that the success of coastline development depends on several factors and that urban planning must cover problems across urban and peri-urban areas and address multidisciplinary issues [15]. The analytical study of the study area was carried out using the Geographic Information System (GIS), which is a system that collects, maintains, stores, analyzes, outputs, and distributes data and spatial descriptive information for specific purposes, help with planning and decision making in relation to city planning [16].

The research focuses on collecting and providing information and data about Burj Al-Burullus city and reaching numbers, statistics and data that reflect the developmental reality of the city through the participation of the local community., and identifying its resources, capabilities and characteristics in order to develop it and presents an attempt to reach a mechanism through which sustainable urban development can be achieved in all economic, social, and demographic aspects.

In addition, it contributes to formulating a vision for the study area and developing a strategy to achieve sustainable urban development in the region with the participation of economic institutions in a way that stimulates these institutions to invest without bearing the occupants of the study area any financial burdens required by that development.

\section{RESEARCH METHODOLOGY}

Data processing has been performed in several stages to acquire up-to-data spatial datasets regarding the study area.

-Stage 1. recent high-resolution satellite image has been obtained, and then digitized through the Arc GIS 10 software.

- Stage 2. A field campaign has been organized to collect field data about land use types.

\subsection{Geographic Information Systems (GIS)}

Specialists have differed in finding a specific definition of GIS, as the definition of this technology varies according to the needs of its users. Below we review the most important definitions of GIS:

It is defined by Star \& Estes as "an information system designed to manage spatial data with geographical coordinates. On the other hand, it combines the management of spatial reference databases, as well as a set of data processing functions", It has also been defined by Adam, N \& Genopathy as "the interdisciplinary field of science, geography, cartography and urban planning" [17].

Zhitao also defined it as "a set of procedures used in data entry, storage, retrieval, mapping and spatial analysis of both metadata and spatial metadata, in order to support decision making in an organization" [18].

Considering these definitions, it can be definition applicable to this article that GIS is a tool that serves to store, retrieve, manage, and analyze spatial data and find solutions to complex problems at the state level. It is noted that countries that preceded the use of geographic information systems relied on them in various national projects such as infrastructure, urban, industrial, and agricultural development, roads, transport services, development plans, the environment and tourism. From this point of view, the power of GIS is to store data spatially in the form of layers. Each layer is associated with an attribute table, which gives simplification in the processing and analysis of stored data. The figure below illustrates the concept of layers in GIS (Figure 2).

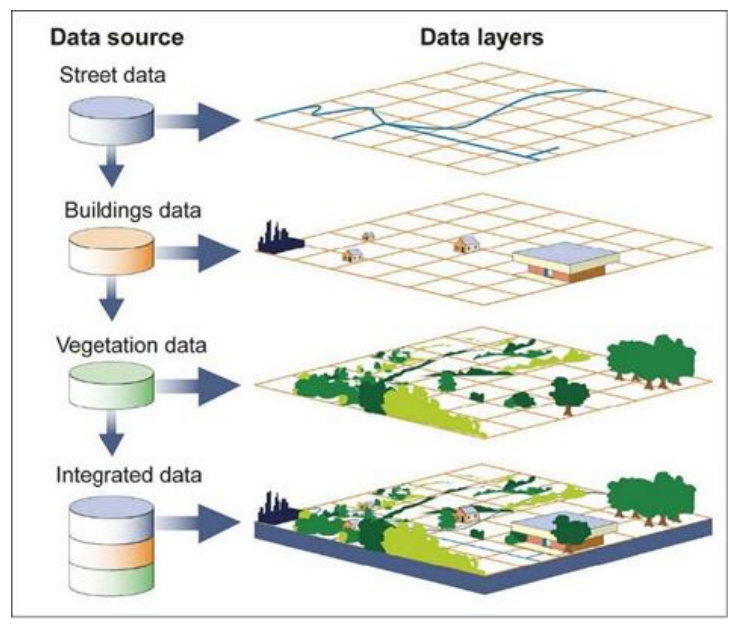

Figure 2. GIS allows multiple layers of information to be displayed on a single map [18] 


\section{CASE STUDY}

Lake Burullus, situated in a middle locus between the two branches of the Nile that form the Delta, is the centerpiece of the five lakes (and associated wetlands): Bardawil in Sinai, Manzala in the eastern Delta, Burullus, Idku in west and Mareotis further west [19].

Lake Burullus is a protected area that extends over an area of 460 square kilometers and lies towards the east of the Rashid branch of the Nile River in Egypt. It is the second largest natural lake in Egypt. Lake Burullus is one of the oldest Egyptian lakes known successively as Lake Botou, Lake Potico, and then Lake Nikiolos. At the end of the Roman rule, it was called Lake Paralus, then Lake Nastrauh, in reference to the Nastrawi region, which was famous in the past, and which is now known as Mistrutah. The lake was finally known as Lake Burullus, in relation to the village of Burullus, which has turned into a city [20].

Lake Burullus is the second largest natural lake in Egypt in terms of area; its area is about 98 thousand feddans after a decrease of $50 \%$ of its original area due to encroachments. It is in Kafr El Sheikh Governorate. It plays a big role in receiving migratory wild birds. It was declared a natural reserve in $1998 \mathrm{AD}$, with 28 islands at great distances where some fishermen and several people live, and livestock and other animals are raised [21].

Lake Burullus is about $300 \mathrm{~km}$ from Cairo, the capital of Egypt Table 1. It contains several landmarks, including: Burj Al-Burullus, which is located between the Mediterranean and the lake, Bogaz Burullus, and the beautiful sandy beaches It also has many monuments, such as: Fanar Al-Burullus, and others, and it is famous for the manufacture of fishing boats and exporting them to many countries. In addition, its residents are proficient and distinguished by their professionalism in the arts of fishing of all kinds. There are many villages beside the lake that are the basis of the fish wealth, such as Al- Banayeen and the Tuesday market.

Table 1. The main details about Burullus Lake Source: Researchers

\begin{tabular}{cc}
\hline Location & Kafr-El Sheik Governorate \\
\hline Arabic name & Lake Burullus \\
\hline English Name & Lake Burullus \\
\hline Average depth & $75-100 \mathrm{~cm}$ \\
\hline Surface area & $460 \mathrm{~km}^{2}$ \\
\hline Max. Width & $6-21 \mathrm{~km}(3.7-13.0 \mathrm{mi})$ \\
\hline Max. Length & $54 \mathrm{~km}(34 \mathrm{mi})$ \\
\hline North border & Mediterranean Sea \\
\hline South border & Agricultural land \\
\hline
\end{tabular}

Kafr El Sheikh Governorate consists of 10 administrative centers followed by 10 cities, and 44 village local units with 206 villages and 1784 farms, Kafr and Naga. In the governorate, there are 589,932 acres of agricultural land, most of which are of the third grade (due to the high salinity). The governorate's production of fish is estimated at 172.2 thousand tons annually. The total population of the governorate is 3.3 million, of whom $77 \%$ are in the countryside and are proficient in agriculture. The industry and crafts sector includes no more than $2 \%$ of the workforce, and they work in Baltim, Matobas, Hamoul and Fuwa.

The center of Baltim is in the far north of the governorate, and it is bordered on the north by the Mediterranean Sea, on the east by the Dakahlia Governorate, and on the west by the
Sidi Salem Center, and on the south by Lake Burullus and Hamoul. Baltim is the capital of the center. The center has two main villages with their dependencies, Burj Al-Burullus and Shehabiyeh.

Lake Burullus is surrounded by five centers (Table 2) (Burullus Center - Al Hamoul - Riyadh - Mutoubas - Sidi Salem) Figure 3. Burullus Center is located at the northeastern end of Lake Burullus, its capital is the city of Baltim, followed by three cities: Baltim, Baltim Resort City, and Burj Al Burullus.

Table 2. Population distribution in the five administrative centers around Lake Burullus

\begin{tabular}{ccc}
\hline \multirow{2}{*}{ District } & \multicolumn{2}{c}{ Population Count } \\
\cline { 2 - 3 } & Actual & $\%$ \\
\hline Burullus & 236.095 & 16 \\
\hline El Hamoul & 290.628 & 20 \\
\hline El Riad & 186.960 & 13 \\
\hline Metobes & 303.537 & 21 \\
\hline Sidi Salem & 439.536 & 30 \\
\hline Total & 3340.609 & $100 \%$ \\
\hline
\end{tabular}
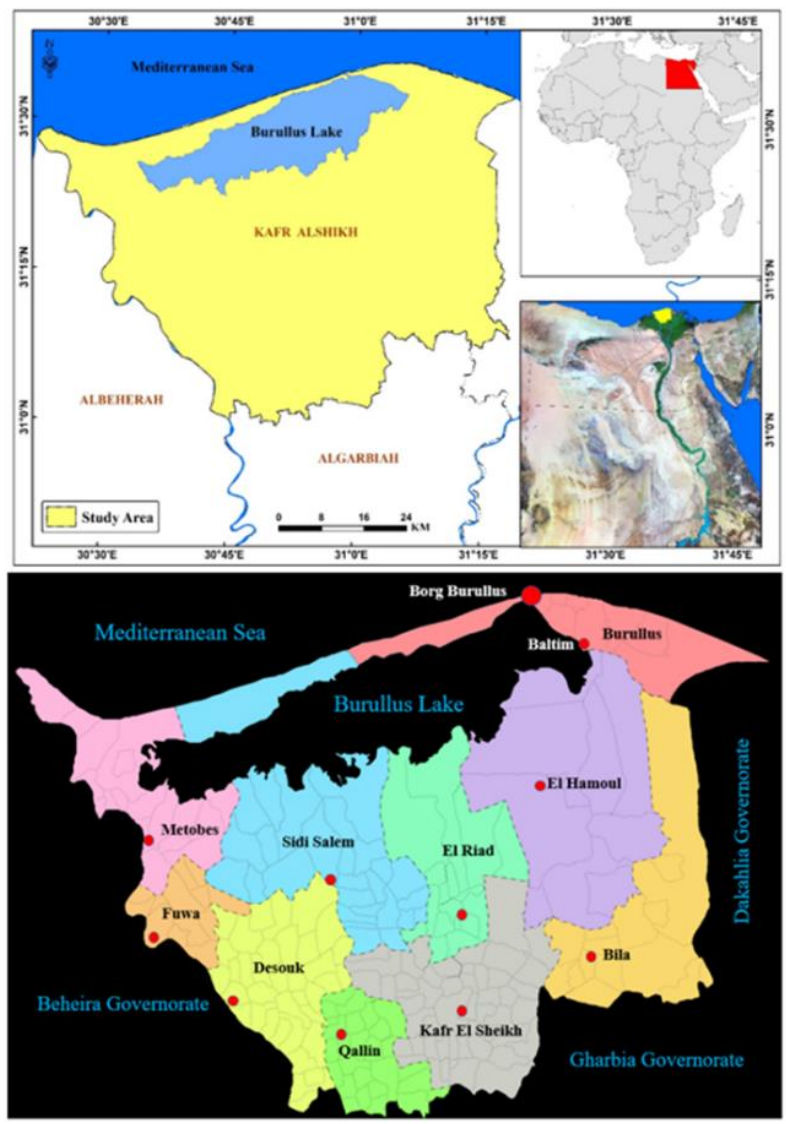

Figure 3. Kafr El Sheikh Governorate consists of 10 administrative centers followed by 10 cities around Lake Burullus

Burj Al-Burullus is a small city located on the northwestern edge of the Burullus Center, between the shore of the Mediterranean Sea and Lake Burullus (Figure 4). It is characterized by the dazzling purity of its atmosphere, its vibrant attractive colors and the absence of unemployment among its residents who work in fishing and manufacturing small and large boats. They have also become skilled in the marine yachting industry.

Urban development challenges represent the biggest motivation for defining a clear development strategy that helps 
find appropriate urban solutions to overcome these challenges [22]. The next part of the research proposes solutions to development challenges and sets up plans to implement urban development as a link between the challenges and development results.

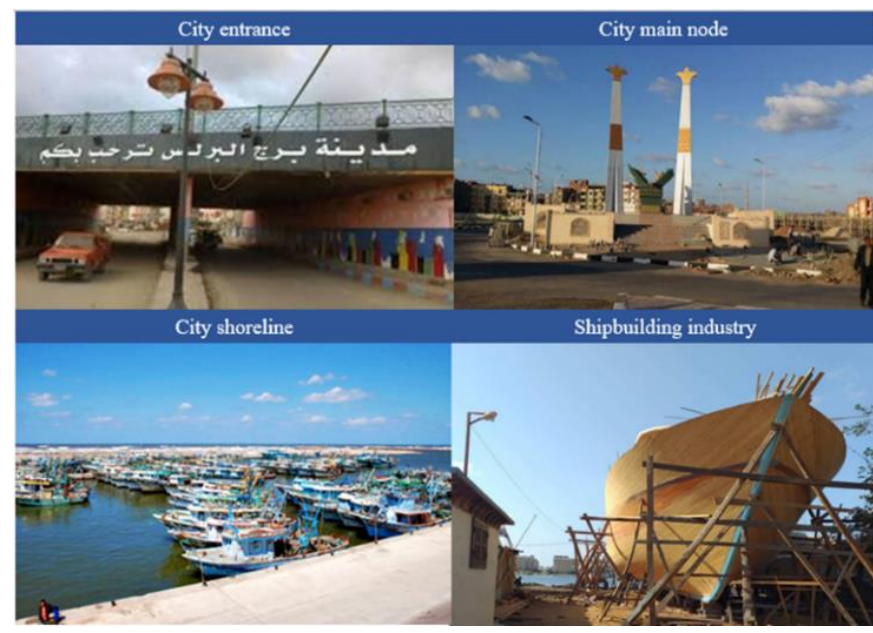

Figure 4. Burj Al-Burullus is a small city located on the northwestern edge of the Burullus Center

\subsection{Previous studies}

Over the past few years, the shoreline of the study area has experienced significant changes in environmental conditions. Some are natural, such as erosion along the coastline, and some are of human origin, such as drying up of wetlands and expansions of agricultural production areas [23]. These changes increase the weakness of the coastal area in relation to sea level rise related to the climate change, especially as natural protection is removed and the potential for land subsidence increases. The main coastal problems within this region are related to erosion due to dynamic factors and low sediment supply from the Nile River after the construction of the Aswan High Dam [24].

Urban sprawl of people to coastal areas is represented in the form of tourism, entertainment, residential and industrial development. There is a steady increase in population growth in the area, while the land area is rapidly eroding. This is expected to lead to serious ecological disruption of the fragile ecosystem unless some effective coastal management measures are taken [25].

The previous studies confirmed that the study area suffers from many problems such as housing models ignore the possibilities of the site and the surrounding environment. This led to the abandonment of its residents, with the absence of development strategies to restore these villages to sustainable neighborhoods. The study area needs to development of site infrastructure, mobility systems, services, energy, and resource management must therefore be combined with the renovation of building forms and occupants to accommodate high density to ensure economic, social, and environmental sustainability [26].

\section{URBAN ANALYTICAL FIELD RESEARCH STUDY}

The purpose of this comprehensive analysis of area-specific opportunities and constraints is to give a clear picture of how the site may encourage or constrain sustainable urban development. Each topic analyzed in this section depends on current conditions and issues Opportunities and constraints are considered for land uses, zoning, and utilities The overall objective of this master plan is to respond as closely as possible to identified opportunities and constraints while minimizing environmental impacts.

Through analyzing the site and studying the potentials and opportunities (Figure 5), the general points in the town were identified. Thus, focus was set on some places such as mosques, fuel stations, hospitals, schools, food sales centers, the municipality building (city hall), football stadiums and other facilities.

The main roads surrounding and inside the town were also classified into three categories according to the importance

and the width of the street. The coastal international road is of great importance, followed by Corniche al-Bahr Street, then the road in the middle of the town to link its east and west, as well as the two most important roads that surround the main square to the coastline. The town is also divided into several planning areas according to its planning nature, especially as the town includes cemeteries, a military zone, an arsenal for building fishing boats and a field for black sand.

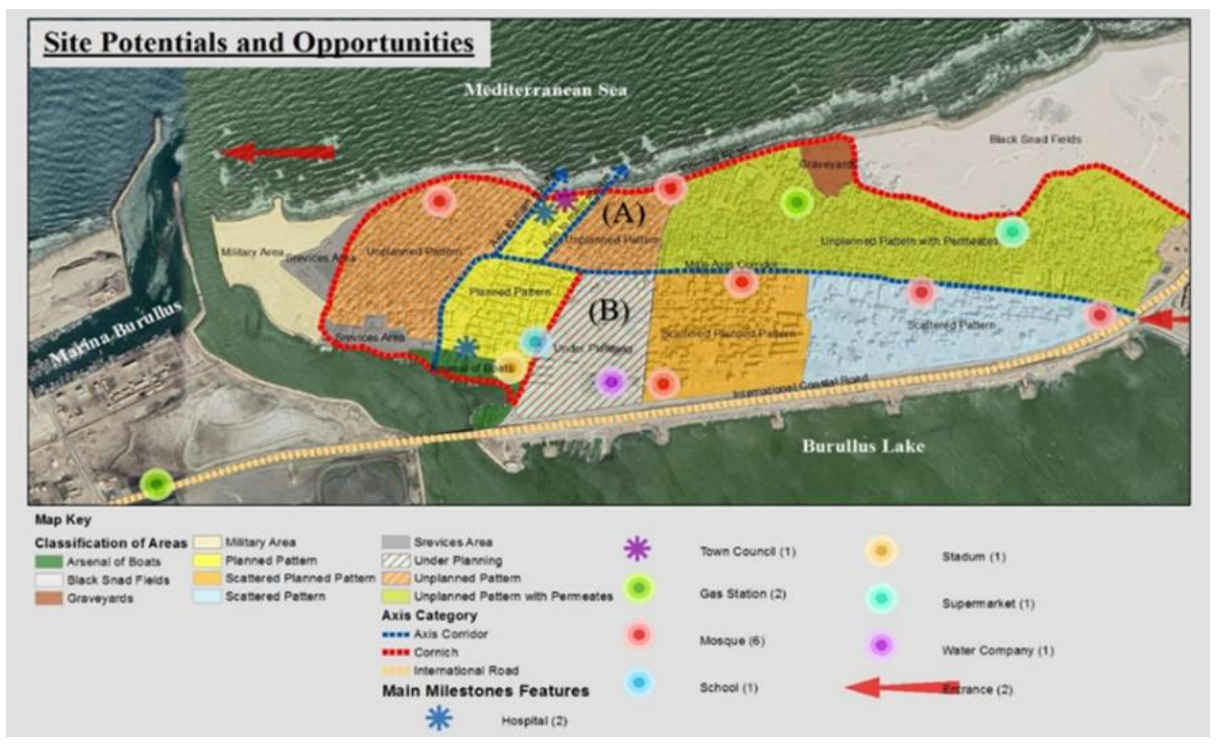

Figure 5. Site potentials and opportunities (Researcher) 
From the study of the urban fabric of the town, it was possible to divide it into planned areas and other planned areas with a scattered texture, in addition to the existence of areas with scattered buildings. The town is also characterized by the presence of unplanned overcrowded urban areas, and semiplanned overcrowded urban areas. However, there are underplanning areas which include planned residential complexes.

Through the previous analysis, it is found that studying the area (A), which has a high unplanned building ratio, is like many areas scattered within Egypt, which may contribute greatly to the generalization of an indicative model to preserve the urban identity of this type of areas.

Nonetheless, the situation in Burj Al Burullus which is adjacent to the south of the area (B), under planning, as in Figure 6, has greatly contributed to directing investments to the area under planning instead of leaving it to unplanned urban sprawl. In addition, this area lies on the eastern side adjacent to a planned area and contains a group of facilities that may be shared with the area.

By studying and analyzing the current situation of the study area (A), as in Figure 6, a set of data that play the main role in setting up the proposed development mechanism and strategy is shown (Table 3 ) as follows.
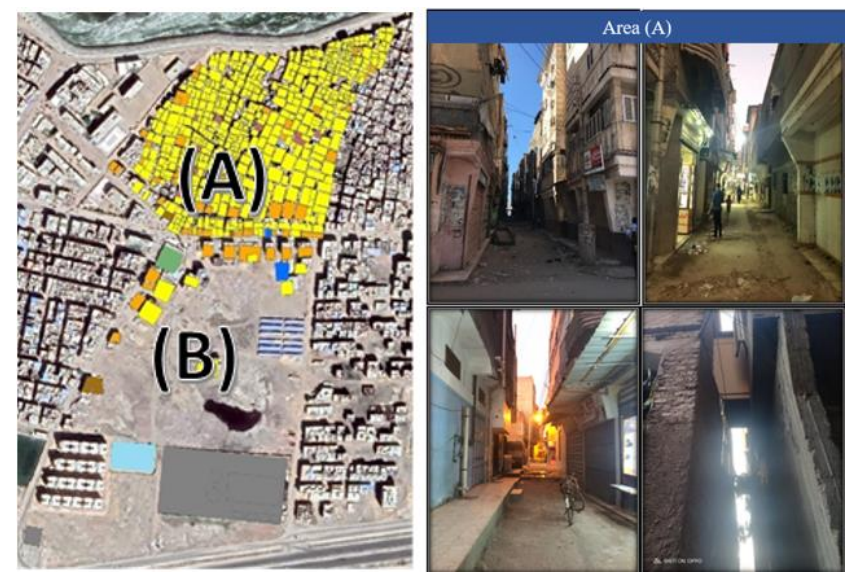

Figure 6. Study area (A) and its relationship to area (B)

Table 3. The research findings

\begin{tabular}{|c|c|}
\hline Elements & Urban characteristics \\
\hline $\begin{array}{l}\text { Structure } \\
\text { System }\end{array}$ & $\begin{array}{l}\text { 1. From the analysis of the structural system of the region, it was found that some houses are shacks, which entails the } \\
\text { necessity to change the housing pattern in the area. } \\
\text { 2. Also, according to the state of the buildings in the area, many of the housing units are in poor construction condition, which } \\
\text { may pose a danger to their occupants, especially buildings higher than two floors. } \\
\text { 3. Its buildings predominantly use red bricks and concrete roofs as a basic structural system for the area. } \\
\text { 4. Some areas suffer from their poor structural condition, especially those built of red bricks with wooden ceilings, or those } \\
\text { where construction waste or mud was used in their building. } \\
\text { 5. The façades are almost non-finished, which gives a feeling that the buildings are poor, despite their recent construction. }\end{array}$ \\
\hline & $\begin{array}{l}\text { An unplanned area - this area does not recognize the foundations of urban planning because its residents carry out the planning } \\
\text { process on their own without the help of specialists. The urban form of this area varies according to the conditions that affect } \\
\text { this formation, such as the location, the method of growth, the network of paths and the characteristics of the buildings. The } \\
\text { urban mass of the region is characterized by a grid-like fabric and narrow streets. } \\
\text { The emergence of an imbalance in the city, where there is a discrepancy in the urban fabric of the city between the planned } \\
\text { and unplanned urban fabric. }\end{array}$ \\
\hline $\begin{array}{l}\text { Land } \\
\text { subdivision }\end{array}$ & $\begin{array}{l}\text { The land division law stipulates that the divider leaves one-third of the area for streets and parks and that the width of the } \\
\text { streets is not less than } 10 \text { meters in addition to other terms and conditions. The division of lands in Burj al-Burullus is usually } \\
\text { carried out with the owners without referring to the planners and without taking into account the requirements contained in } \\
\text { the division law. Therefore, the streets are narrowed, and the area of land plots is less than stipulated by law and construction } \\
\text { on the entire area. }\end{array}$ \\
\hline Streets & $\begin{array}{l}\text { Buildings and streets spontaneously arose in an unorganized manner, without direction or supervision. } \\
\text { The narrow streets and their incompatibility with the heights of the buildings. } \\
\text { The streets in the area differ from other planned areas in terms of widths, conditions, and shapes. } \\
\text { The poor condition of the road network and footpaths, their inadequacy with the volume of traffic on them, and the difficulty } \\
\text { of using them in emergency situations. }\end{array}$ \\
\hline Buildings & $\begin{array}{l}\text { Many buildings in the area are dilapidated. } \\
\text { The construction processes are carried out far from modern systems, under the supervision and instructions of small } \\
\text { contractors or craftsmen. } \\
\text { The engineering and construction weakness and the instability of the buildings. Most of the buildings were built quickly, and } \\
\text { consequently are subject to collapse. } \\
\text { Buildings vary in heights - the vast majority of buildings in the area are three or four floors. }\end{array}$ \\
\hline & $\begin{array}{l}\text { The study area lacks parks, green spaces, open areas, and the absence of an outlet for the population amid the severe } \\
\text { congestion of buildings and residents, despite its location in a distinct strategic location. }\end{array}$ \\
\hline Services & $\begin{array}{l}\text { All informal areas suffer from the lack of services, which are not commensurate with the size of the population and are less } \\
\text { in level than those in the official areas. Green spaces, cultural and entertainment services, and public buildings are virtually } \\
\text { absent. } \\
\text {. Lack of numbers and types of educational, health and entertainment services. } \\
\text { Green spaces are virtually non-existent, as well as cultural, entertainment and administrative services. } \\
\text { Lack or inefficiency of public utility networks in general. } \\
\text { Lack of an integrated system for street cleaning and garbage collection in an orderly manner from homes and streets. }\end{array}$ \\
\hline $\begin{array}{l}\text { Aesthetic } \\
\text { aspects }\end{array}$ & $\begin{array}{l}\text { Narrow and straight streets. The buildings erected on their sides are badly viewed. There is a terrible residential convergence } \\
\text { that indicates a general deterioration of the urban environment. This area is newly constructed, but it is a belt that suffocates } \\
\text { the city of Mansoura and prevents the growth of its roads and distorts the beauty of its surrounding nature. }\end{array}$ \\
\hline
\end{tabular}


Therefore, to raise the low level of housing in the shacks, it is necessary to:

- Completely remove the shacks and compensate their occupants with alternatives that are being studied, as well as dilapidated housing units that may pose a danger despite their restoration, namely, buildings are made up of more than two floors.

- Replace poorly structured buildings with good ones that help in the development of the area. In addition, it is necessary to begin negotiations with the occupants to move them within the same geographical area, which allows improving the urban fabric of the area as a result of providing spaces that give the opportunity for urban development and creating urban spaces while preserving the urban pattern in terms of fabric and character.

- Paying attention to the economy. Therefore, sustainable societies are reasonably economic societies that ensure that services are provided to all residents at the same level and costs to ensure justice.

- Identifying sites and investment projects that contribute to increasing economic activity to create different job opportunities to reduce poverty and unemployment.

The total area of the shacks can be calculated by deducing the areas that will be built to move the occupants within their geographical scope. The same concept can also be applied to the same deteriorating structural condition.

Methods of analysis will be used in geographic information systems to count the shacks and calculate their areas, which allow the possibility of anticipating the size of the funding required to provide decent buildings, which helps determine the feasibility of investment in those areas and the expected economic returns.

\section{RESULTS}

Based on the Egyptian Building Law No. 119 of 2008 and its implementing regulations regarding village planning, the area of the plot of land designated for construction must not be less than 70 square meters. The plot of land must have at least one side on the road, where the length of the side overlooking the road is no less than 7 meters. Likewise, road widths may not be less than 6 meters, while any block may not exceed 150 meters in length. The maximum height of the buildings on both sides of the road shall not exceed 1.5 times the width of the road. The National Organization for Urban Coordination issued a set of guidelines, where one of those guidelines dealt with the ratio of the length to the width of urban spaces, which is defined as $3: 2$, and the ratio of the width of the urban space to the height of the buildings overlooking as 3: 4. For example, for buildings with a height of 9 Meters, the width of the urban space shall be 7.5 meters.

The problem lies in the northern part of the main road that passes horizontally through the city, as it includes relatively large areas of shacks used as housing, which represent $11 \%$ of the total built-up land area or suitable for construction land, as shown in Figure 7. To benefit from the spaces on which these shacks are built, various methods have been proposed. These methods differ according to the location of the shack and its suitability to create urban spaces within the urban cluster that allow the existence of investment activities. These methods include:

1. Some shacks are not suitable to be used as a new urban space or to be replaced with a new building due to the Egyptian building codes that restrict the minimum area of land for building to 70 square meters Therefore, being adjacent to one of the dilapidated buildings provided an opportunity to combine them as one piece of land for construction, which provides a suitable space for construction in accordance with the law. In addition, it provided the residents of the dilapidated buildings with a new suitable residence. On the other hand, the process includes merging the property and establishing a three-story building.

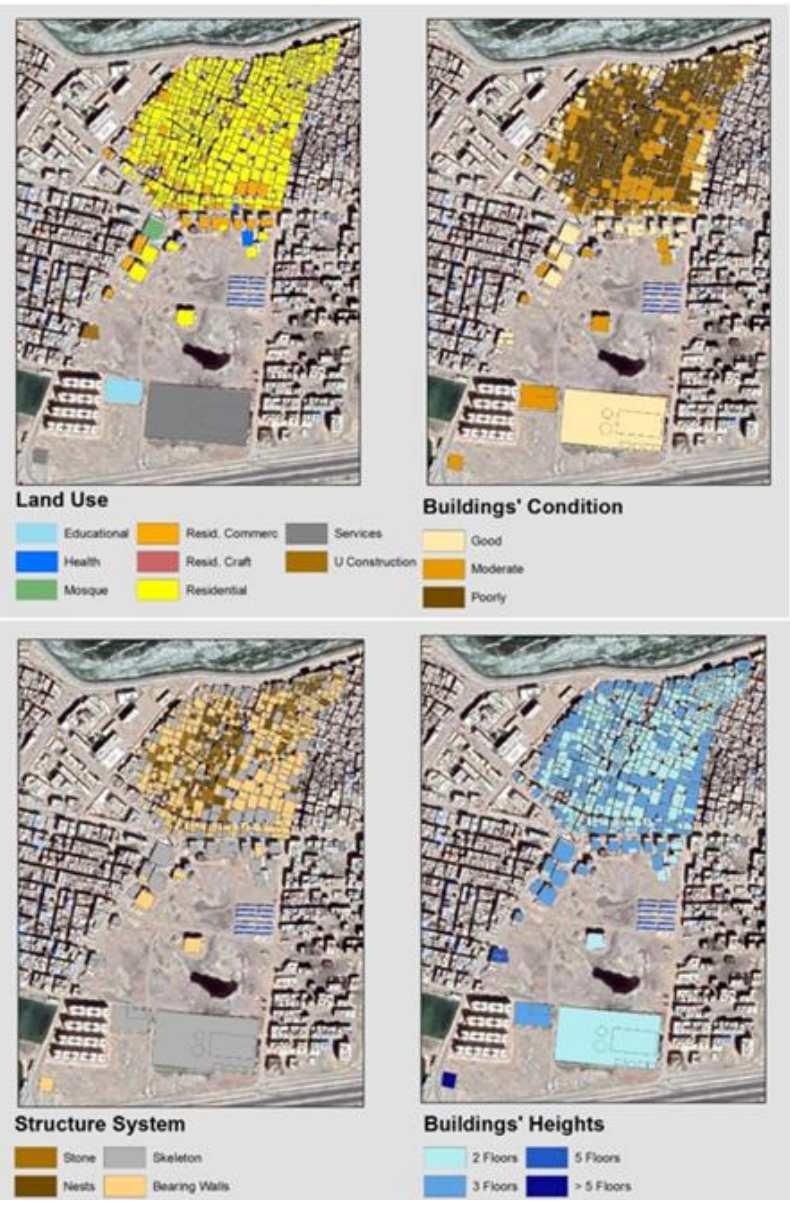

Figure 7. The uses - heights - condition (good - medium bad) and structure system of the buildings in study area

2. Transferring the occupants of some shacks to alternative housing that was available as a result of replacing other shacks with new buildings and making use of those spaces to create urban spaces within the urban mass.

3. Replacing some shacks with new buildings in their same places and limits of their possession, but with a height of three floors instead of one floor.

Dilapidated buildings of poor construction represent $55 \%$ of the total built-up land area or area suitable for construction, as shown in Figure 8. They represent an imminent danger to lives and property, which creates a need for wise dealings to guarantee the safety of their occupants and at the same time maximize their use in terms of investment or planning. Different methods have been proposed to deal with these buildings in accordance with their location. These methods include the following: 
1. Some dilapidated buildings are adjacent to some shacks whose areas are less than 70 meters by merging the ownership of the two plots of land and replacing them with one new three-story building.

2. Some of the dilapidated buildings whose location can be invested so that the plot of land they occupy can be part of a new urban space that contributes, in terms of planning and economy, to creating a good investment opportunity. Thus. It is possible to expropriate its ownership and compensate the occupants with alternatives offered by the new facilities mentioned before.

3. Restoration and consolidation of the remaining dilapidated buildings. The restoration and consolidation may include the replacement of major structural elements in the building.

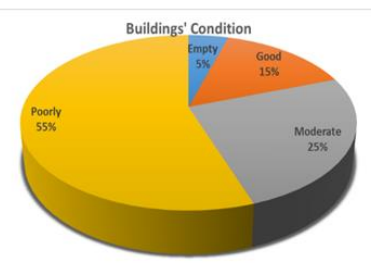

Buildings' condition

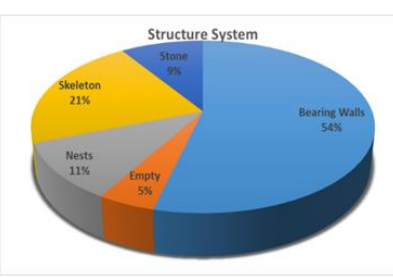

structural systems
Figure 8. The building condition and Building structural systems in the Study area and the relative relationships between each other

One of the most important characteristics of the urban mass under study is that it contains unused and abundant areas that reach $5 \%$ of the total built-up land area or area suitable for construction, which makes it a good opportunity for investment. Different methods have been proposed to deal with it in accordance with the location of the building. These methods are:

1. Building on them to be included into the urban mass so that they are used as determinants of urban spaces that lack spatial determinants, which helps in finding compensatory solutions for some occupants of shacks and dilapidated buildings whose properties will be expropriated.

2. Transforming some of the buildings which location allows employing them as urban spaces within the urban mass either individually or by adding them to areas that will turn into urban spaces of shack land or dilapidated buildings that will be expropriated.

To maintain streets with a width of not less than 6 meters, this must be done when constructing the new buildings mentioned above, so that the building boundary of the new building returns by half the width of the road measured from the middle of the current road. The new construction or what will be replaced by a new three-story building will provide more spaces for both residential and commercial occupancy for investment. The new buildings have replaced shacks of only one floor and dilapidated buildings, most of which are only two floors high, thus providing a surplus of space available for housing and other activities.

The total of the permeated lands to be built, the shacks, and the dilapidated buildings to be replaced are built with a ground floor + two floors, provided that the building boundary is set back from the road, with half the difference between the width of the road and the 6 meters, which is the minimum street widths in Egyptian villages according to the law.
The empty lands that will be built on are used as temporary housing for the occupants of the houses that will be replaced. Then, the occupants of the housing that will be demolished are transferred therein.

From the above, it is found that a set of Action to be taken towards re-planning the study area, which is shown in the following Table 4:

Table 4. Suggest different actions of dealing with the study. area

\begin{tabular}{|c|c|}
\hline Actions & Description \\
\hline Build & Space areas to be built \\
\hline Merge & $\begin{array}{c}\text { Shacks less than } 70 \text { meters will be integrated } \\
\text { with shacks or dilapidated buildings next to } \\
\text { them }\end{array}$ \\
\hline Preserve & $\begin{array}{l}\text { Existing buildings require preservation of their } \\
\text { condition with no additional floors being } \\
\text { permitted }\end{array}$ \\
\hline Repair & $\begin{array}{l}\text { Existing buildings in poor structural condition, } \\
\text { requiring restoration with additional floors } \\
\text { being permitted }\end{array}$ \\
\hline Replace & Single shacks will be replaced in their place \\
\hline Space & Space areas are maintained \\
\hline Transfer & $\begin{array}{l}\text { Shacks or dilapidated buildings that will be } \\
\text { turned into square }\end{array}$ \\
\hline
\end{tabular}

Using GIS technology, the following could be determined:

1. The area of shacks that are less than 70 meters (separate, so that it cannot be included with other shacks to create an urban space).

2. Less than 70 meters buildings in poor condition (adjacent to individual shacks to be included in the construction of a residential building to compensate the occupants).

3. The adjacent parts in which conditions (1) and (2) are fulfilled to determine which of them will be joined to obtain plots of land in accordance with the Egyptian law of an area greater than 70 square meters where the width of the land on the street is greater than 7 meters (Table 5).

The process is carried out in a minimalistic way to avoid clashes with multiple owners to encourage the other owners as per the result of the experiment Figure 9.

Table 4 represents the action parameters of evaluation but Table 5 shows the values of these action parameters which these values represent in map Figure 9 and pie diagrams. By analyzing the results, it is found that the total areas of currently plots of land, whether buildings or shacks, including unused vacant lands, are 78959 square meters. With a total surface area of buildings and shacks estimated at 16, 8002 square meters. In addition, by applying the proposed methodology, it is found that the built area -Foot Print- decreases by 3234 square meters, equivalent to $4.1 \%$, to become 75725 square meters, as shown in Figure 10.

The total built-up surface of floors also increased by 14,307 square meters, equivalent to $8.52 \%$, to become 182,309 square meters, as in Figure 2, which increases the chances of attracting capital for investment and benefiting from the increase in floor surfaces.

Furthermore, urban spaces that have been created to improve the urban environment without disturbing the urban fabric are an opportunity to increase the investment return as increasing those urban spaces from 3603 square meters to 4,743 square meters, equivalent to $32 \%$ as in Figure 4, which in turn creates high investment opportunities as well as social and cultural values. 
Table 5. The proposed classification for re-planning

\begin{tabular}{|c|c|c|c|c|c|c|c|c|}
\hline $\begin{array}{c}\text { Action } \\
\text { Area } \\
\end{array}$ & $\begin{array}{c}\text { Space } \\
\text { to Built }\end{array}$ & Merge & Preserve & Repair & Replace & $\begin{array}{l}\text { Remain } \\
\text { Space }\end{array}$ & Transfer & Totals \\
\hline Sum of Existing Footprint Include open spaces & 1.858 & 3.069 & 31.688 & 32.965 & 4.267 & 1.745 & 3.367 & 78.959 \\
\hline $\begin{array}{l}\text { Sum of existing Floor's area exclude Open } \\
\text { Spaces }\end{array}$ & 0.00 & 4.008 & 81.017 & 73.706 & 4.271 & 0.00 & 5.00 & 168.002 \\
\hline $\begin{array}{l}\text { Existing Average Floors Count } \\
\end{array}$ & 0.00 & 1.30 & 2.51 & 2.16 & 1.00 & 0.00 & 1.42 & 1.20 \\
\hline Sum of New Floors Area (Extension in Height) & 5.574 & 5.200 & 0.00 & 0.00 & 8.534 & 0.00 & 0.00 & 19.307 \\
\hline Sum of Total Floors Area (Existing + New) & 5.574 & 9.207 & 81.017 & 73.706 & 12.805 & 0.00 & 0.00 & 182.309 \\
\hline New Average Floors & 3.00 & 3.00 & 2.51 & 2.16 & 3.00 & 0.00 & 0.00 & 1.95 \\
\hline New Footprint & 1.858 & 3.069 & 32.334 & 34.196 & 4.268 & 0.00 & 0.00 & 75.725 \\
\hline
\end{tabular}

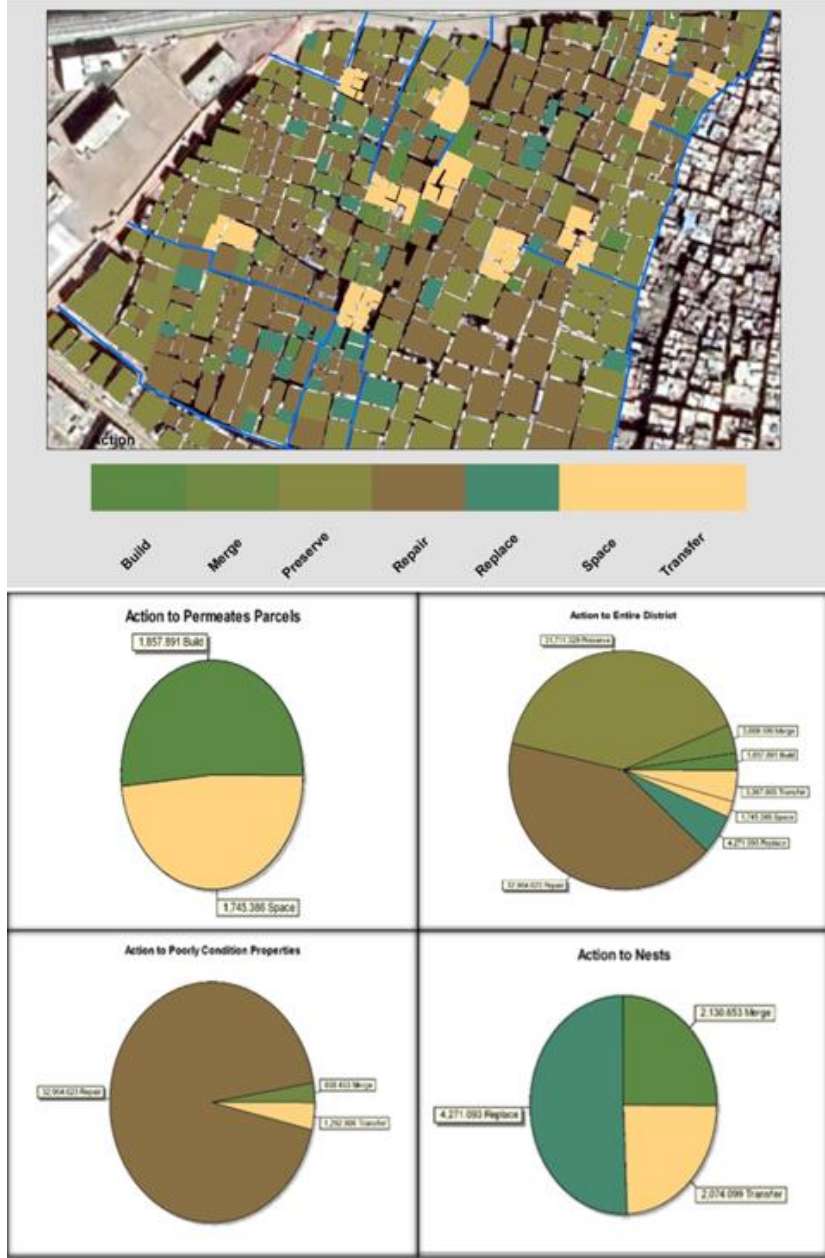

Figure 9. The proposed classification for re-planning

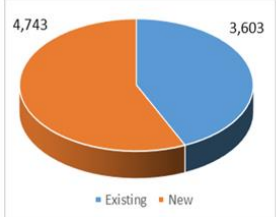

Total planes of urban spaces

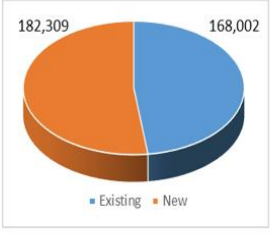

Total flat floors

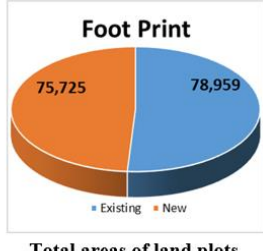

Total areas of land plots
Figure 10. The total planes of (planes of urban spaces- flat floors - areas of land plots) in the Study area

\section{RECOMMENDATIONS}

Coasts are considered one of the most important natural resources in the world, due to their beautiful sandy beaches, waters of coral reefs, neighborhoods, seaweeds and islands with distinct characteristics, in addition to the clear economic, cultural and political potentials.

The marine environment in coastal areas faces severe environmental risks by pollutants resulting from the misuse of the coast, the spread of inappropriate uses and expansion of the level of urbanization at the expense of natural characteristics. Therefore, a rapid intervention is required to protect the ecological balance in the coastal region, especially the processes of controlling unplanned urban movement.

The study suggests some recommendations on the developmental level, to achieve sustainable thinking within the development of urban societies, namely: enhancing the relationship between economic environmental social development and urban development, as urban projects are considered as the tangible interpretation of the economic, environmental, and social strength of any society.

Sustainable thinking must be incorporated during the development of urban development strategies given the importance of preserving natural resources and properly exploiting them, as they form the cornerstone of most development projects. Therefore, these strategies will achieve environmental balance and contribute to the benefit of current societies and future generations.

It is necessary to define an appropriate concept for urban coastal development that depends on the optimum utilization of the advantages in the coastal potentials and the difficulties facing development and investment in coastal areas. In addition, it is significantly important to identify the methods by which new ideas for development can be achieved such as discovering untapped potentials and re-employing them and identifying how to diversify the utilization of areas of urban coastal development.

The establishment of a supreme council or a special department to manage urban development in coastal areas is one of the most important methods for setting comprehensive development plans which aim to conduct studies of the current situation, determine requirements for the advancement of coastal areas, and establish comprehensive development plans to ensure coordination between these plans and developmental programs for the agencies in charge of implementation. Thus, it would be possible to controls the urban development processes on the coasts.

The success of the comprehensive development of coastal areas hinges on merging the strategic plans of the various development sectors with the urban strategy of these areas and the urban development plans for the cities and residential communities located on them in addition to the plans and programs for industrial and productive activities when preparing the comprehensive development plans for the coasts. Therefore, it is necessary to take those plans and strategies into account in addition to the requirements imposed by environmental characteristics and security necessities. 


\section{REFERENCES}

[1] Nassar, D.M., Elsayed, H.G. (2018). From informal settlements to sustainable communities. Alexandria Engineering Journal, 57(4): 2367-2376. https://doi.org/10.1016/j.aej.2017.09.004

[2] Wallace, J. (2014). Cities and Stability: Urbanization, Redistribution, and Regime Survival in China. Oxford University Press.

[3] White, R., Turpie, J., Letley, G.L. (2017). Greening Africa's cities: Enhancing the relationship between urbanization, environmental assets, and ecosystem services. World Bank. https://doi.org/10.1596/26730

[4] Viana, C.M., Oliveira, S., Oliveira, S.C., Rocha, J. (2019). Land use/land cover change detection and urban sprawl analysis. In Spatial Modeling in GIS and R for Earth and Environmental Sciences, 621-651. https://doi.org/10.1016/B978-0-12-815226-3.00029-6

[5] Ragheb, A.A., EL-Ashmawy, R.A. (2020). Urban waterfront development for designing space in coastal cities. International Journal of Sustainable Development and Planning, 15(3): 345-352. https://doi.org/10.18280/ijsdp.150311

[6] Dariah, A.R., Salleh, M.S., Saniff, S.B.M., Ernawati. (2020). Comparative study of sustainable development planning in Southeast Asia countries. International Journal of Sustainable Development and Planning, 15(4): 469-476. https://doi.org/10.18280/ijsdp.150407

[7] Blakely, E.J., Leigh, N.G. (2013). Planning Local Economic Development. Sage.

[8] Rogerson, C.M. (2006). Pro-Poor local economic development in South Africa: The role of pro-poor tourism, Local Environment, 11(1): 37-60. https://doi.org/10.1080/13549830500396149

[9] Omran, E.S.E., Negm, A.M. (2018). Adaptive Management Zones of Egyptian Coastal Lakes. In: Negm A., Bek M., Abdel-Fattah S. (eds) Egyptian Coastal Lakes and Wetlands: Part I. The Handbook of Environmental Chemistry, vol 71. Springer, Cham. https://doi.org/10.1007/698_2017_192

[10] Ragheb, A., El-Ashmawy, R. (2021). Strategic actions of urban development to define the intervention policies of slums. City Territ Archit 8, 10. https://doi.org/10.1186/s40410-021-00139-w

[11] El Kafrawy, S.B., Ahmed, M.H. (2020). Monitoring and protection of Egyptian northern lakes using remote sensing technology. In: Elbeih S., Negm A., Kostianoy A. (eds) Environmental Remote Sensing in Egypt. Springer Geophysics. Springer, Cham. https://doi.org/10.1007/978-3-030-39593-3_9

[12] Younis, A.M. (2018). Environmental impacts on Egyptian Delta Lakes' biodiversity: A case study on Lake Burullus. In: Negm A., Bek M., Abdel-Fattah S. (eds) Egyptian Coastal Lakes and Wetlands: Part II. The Handbook of Environmental Chemistry, vol 72. Springer,
Cham. https://doi.org/10.1007/698_2017_120

[13] Ragheb, A.A. (2018). Sustainable urban planning for protecting salt lakes; case study Bardawil lake, North Sinai, Egypt. International Journal of Scientific \& Engineering Research, 9: 1191-1197.

[14] Ragheb, A., Abdel-Razek, S., Moanis, Y. (2020). Shoreline alteration rate and urbanization in the Burullus region. Derivative Works: 151.

[15] Robert, K., Alder, J. (2017). Coastal Planning and Management. CRC Press.

[16] Burrough, P.A., McDonnell, R., McDonnell, R.A., Lloyd Christopher, D. (2015). Principles of Geographical Information Systems. Oxford University Press.

[17] Goodchild, M., Egenhofer, M.J., Fegeas, R., Kottman, C. (2003). Interoperating Geographic Information Systems. Vol. 495. Springer Science \& Business Media.

[18] Su, Z.T. (2003). Development of GIS as an information management system: A case study for the Burden Center. LSU Master's Theses, 696.

[19] Shaltout, K.H. (2017). Reed Products from Lake Burullus, Egypt. In: Finlayson C. et al. (eds) The Wetland Book. Springer, Dordrecht. https://doi.org/10.1007/978-94-007-6172-8_211-8

[20] Elbeih, S.F., Negm, A.M., Kostianoy, A. eds. (2020). Environmental Remote Sensing in Egypt. Springer Nature. https://doi.org/10.1007/978-3-030-39593-3

[21] Hossen, H., Negm, A. (2016). Change detection in the water bodies of Burullus Lake, Northern Nile Delta, Egypt, using RS/GIS. Procedia Engineering, 154: 951958. https://doi.org/10.1016/j.proeng.2016.07.529

[22] Salem, M., Tsurusaki, N., Divigalpitiya, P., Osman, T., Hamdy, O., Kenawy, E. (2020). Assessing progress towards sustainable development in the urban periphery: A case of greater Cairo, Egypt. International Journal of Sustainable Development and Planning, 15(7): 971-982. https://doi.org/10.18280/ijsdp.150701

[23] Masria, A., Negm, A.M., Iskander, M. (2016). Assessment of Nile Delta Coastal Zone Using Remote Sensing. In: Negm A. (eds) The Nile Delta. The Handbook of Environmental Chemistry, vol 55. Springer, Cham. https://doi.org/10.1007/698_2016_55

[24] Masria, A., Negm, A., Iskander, M., Saavedra, O. (2014). Coastal zone issues: A case study (Egypt). Procedia Engineering, $\quad 70$ : 1102-1111. https://doi.org/10.1016/j.proeng.2014.02.122

[25] Lakshmi, S.A., Edward, J.K.P. (2010). Coastal issues and management strategy for Sagar island in bay of Bengal. Environmental Sciences, 2(5): 96-101.

[26] Akl, M.H., Sheta, S.A., Hegazy, I.R. (2020). Population density and solar radiation effect on the residential buildings forms: Case study of the Graduates villages at El-Burullus Lake. Bulletin of the Faculty of Engineering. Mansoura University, 40(1): 1-11. https://doi.org/10.21608/BFEMU.2020.101052 